\title{
Sustainability assessment for urban underground utility infrastructure projects
}

1 Aryan Hojjati MEng, AFHEA Doctoral Researcher, School of Engineering, University of Birmingham, Birmingham, UK (corresponding author: a.hojjati@pgr.bham.ac.uk)

2 Ian Jefferson BEng, DIS, PhD, FGS

Professor of Geotechnical Engineering, Head of Education, School of Engineering, University of Birmingham, Birmingham, UK
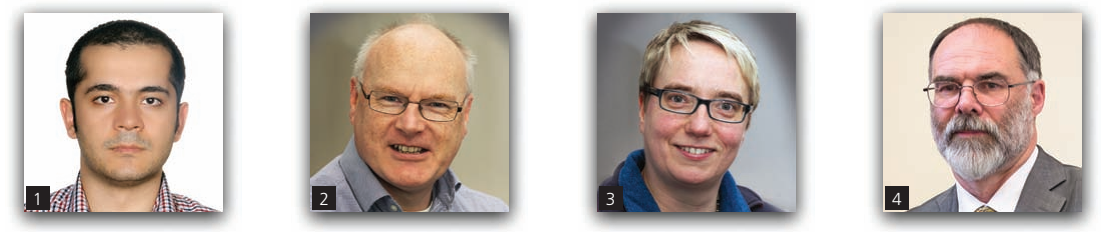

Utility infrastructure systems, designed well, have a pivotal role to play in improving the sustainability of cities due to their critical functionality in urban environments. Equally, utility streetworks - installation, maintenance and upgrading activities - can adversely impact the local and global economies. The inaccurate location of pipes and cables lengthens streetworks operations and can exacerbate traffic congestion, notably resulting in major delays in cases of third-party utility damage, while vehicle emissions and wasted energy are other examples of the adverse impacts of congestion caused by streetworks operations. The total impact of utility infrastructure projects can be assessed only by evaluating all economic (both direct and indirect), social and environmental costs of streetworks. A dedicated tool for evaluating the sustainability impacts of utility streetworks is required. This paper provides the basis for utility streetworks sustainability assessments, and hence full costing, by critically reviewing existing sustainability assessment tools and making recommendations for developing a total sustainability costing model and indicator system.

\section{Introduction}

Traditional civil engineering practices are being challenged by the changing contexts in which they are being carried out (extreme climatic conditions, natural resources scarcity etc.) and their contribution to these changing contexts (greenhouse gas emissions, global warming). In response, sustainable development, and the sustainability agenda more widely, has been made explicit internationally in development planning for the built environment. Ainger and Fenner (2014) state that the notion of sustainable development is often perceived as vague, contradictory and uncomfortable, as it commonly poses challenges to traditionally acceptable solutions. The term 'sustainable development' is increasingly used by academic and industry professionals, and even the aware public, but there is no fixed definition that can truly explain the concept (Elghali et al., 2008). The concept of sustainable development can be traced back to 1987 in the Report of the World Commission on Environment and Development: Our Common Future and the most quoted Brundtland definition of sustainable development.

Sustainable development is development which meets the needs of the present without compromising the ability of future generations to meet their own needs. (Brundtland, 1987: p. 24)
The Forum for the Future offered another definition for sustainable development.

Sustainable development is a dynamic process, which enables all people to realise their potential and improve their quality of life in ways that simultaneously protect and enhance the Earth's life support systems. (Chambers et al., 2008: p. 3)

The American Society of Civil Engineers defines sustainability as follows.

A set of environmental, economic and social conditions in which all of society has the capacity and opportunity to maintain and improve its quality of life indefinitely without degrading the quantity, quality or availability of natural, economic, and social resources. (Keaton, 2014: p. 3818)

While there are many other definitions for sustainability and sustainable development, and a comprehensive review lies beyond the scope of this paper, there are common core threads that should fundamentally challenge the civil engineer. Given that interventions in utility infrastructure systems impact the social environment, the built environment and the natural environment, 
infrastructure projects have a particular importance as necessary exemplars of sustainable development. A tool that enables engineers to make the implementation of sustainability principles in these projects explicit, and beneficially influence practices, therefore has considerable value and reach.

Utility service provision is a critical aspect of urban environments, as ever more people live in cities - it is estimated that $70 \%$ of the world's population will be urban by 2050 (Sterling et al., 2012) - and hence, sustainable and resilient engineering solutions are required to address the problems posed by the increasingly complex and interdependent infrastructures that deliver them. This pattern of growing complexity and interdependency is particularly true for the pipeline and cable networks that are buried underneath city streets. As a direct consequence of this engineering challenge, and the piecemeal development of most urban infrastructure systems, the streetworks operations associated with utility placement, maintenance and upgrading operations are costly. Ten years ago direct construction costs in the UK alone were estimated at $£ 1.5$ billion, of which $\sim £ 150$ million was estimated to be attributed to third-party damage, while indirect costs (including social and environmental impacts) were estimated at $£ 5.5$ billion per year (McMahon et al., 2006).

It is evident that the true total cost of any infrastructure-related activity can only be measured by including all elements of the three pillars of sustainability - that is, considering direct and indirect economic costs along with both social and environmental impacts (Hunt et al., 2014; Jung, 2012). Consequently, if the potential benefits of reducing the effects of utility streetworks are to be realised (inter)nationally, the costs and non-costed impacts across all three pillars of sustainability have to be determined - quantitatively where possible and qualitatively where not. Due to the widely varying nature of utility infrastructure projects and the very large number of streetworks carried out around the world, a robust, holistic and easy-touse sustainability evaluation tool bespoke to utility streetworks is needed. This paper, which focuses on sustainability costs and impacts of utility streetworks in urban areas, contributes to this endeavour by reviewing existing sustainability assessment tools and frameworks with a view of their applicability to urban utility infrastructure projects. It discusses the advantages and disadvantages of the existing sustainability assessment systems and concludes with recommendations in the form of a proposal for a new total sustainability costing model and evaluation methodology for such projects. This proposed framework will, for the first time, enable planners, designers and developers to make informed decisions of future buried infrastructure projects, ensuring that they consider the impact of the projects in a holistic manner taking account of economic, societal and environmental impacts. Moreover, this new tool will consider not only the construction phase but also the maintenance phase of a project to ensure that any intervention is resilient for the future.

\section{Traditional against more sustainable engineering alternatives for utility streetworks}

Utility infrastructure in the UK has been largely developed during the last two centuries; thus, a great volume of ground has been excavated and different utilities (including pipes and cables manufactured from a wide range of materials) have been placed below the ground surface. From the early town gas pipes in 1807 and sewer networks in 1866 to the introduction of the late twentiethcentury communications infrastructures, numerous co-located systems now exist beneath city streets; they perform and deteriorate in different ways and all need maintenance, expansion and/or upgrading that is sympathetic to their long-term behaviours (Rogers and Hunt, 2006). Maintenance and renewal typically involve excavation at significant economic cost, but far greater associated cost. In recognition of this, and as an incentive to make streetworks more efficient and consider other (e.g. trenchless) approaches, road occupancy charges have been levied to utility companies, such as the $£ 1000$ per day levy introduced by Camden and Middlesbrough Borough Councils in the UK (Balance et al., 2002).

While this recognition and incentive is to be applauded, it fails to address the magnitude of the situation. Accepting that the annual direct cost of streetworks in the UK is well beyond $£ 1$ billion and using the multiplier of 3.7 proposed by McMahon et al. (2006) yields a very large sum indeed; thus, a comprehensive evidence base of the impacts of streetworks is needed if a full appreciation of the problem, and effective mitigation, is to be achieved. Interrupting traffic flow, causing damage to tree roots, the production of large amounts of waste and pollution (to soil and air) and suchlike impacts are commonly quoted problems of traditional streetworks operations (Kolator, 1998), yet they remain abstract in relation to their relevance to any one project and, therefore, easier to ignore. As stated by Rogers and Hunt (2006), the quality of life in the twenty-first century is greatly dependent on invisible utility services systems and yet the quality of life is, often unnecessarily, compromised by disruption when intervening in these systems.

These utility service systems are coming under ever-greater pressure due to the combined influences of population growth (with an estimated 10 million more people in the UK by the year 2065 ) and, thus, enormous demand for new housing, urbanisation (a greater proportion of the population living in cities) and city densification (in an effort to combat urban sprawl) and the aspiration for new ecotowns (towns designed to facilitate a lifestyle that has as little impact on the environment as possible; hence, new ways of service provision). To these should be added the issues of outworn utility infrastructure requiring replacement and upgrading as well as services for new developments connecting to older infrastructure that is often overstretched and, in some cases, insufficient to cope with the additional load. Traditional methods of utility placement, maintenance and upgrading are becoming unsustainable, mainly because of the many associated social, economic and environmental costs. This 
necessitates the consideration of alternative engineering practices such as trenchless technologies (TTs) and multi-utility tunnels (MUTs), yet a barrier to their introduction is an evidence base of the overall increase in value delivered to set against the cost of their implementation - that is, the basis of a compelling business case for their routine introduction into engineering practice.

\subsection{Traditional open-cut trenching}

Open-cut excavation, or trenching, as a traditional engineering method for utility placement underground has been used for more than 200 years in the UK (Rogers and Hunt, 2006), and the method has not changed much in terms of its basic engineering approach over this period (Figure 1). The most important changes include mechanisation of the processes for excavation and reinstatement, hydraulic systems to support excavation walls and advances in the quality of pipe materials (Hunt et al., 2014), along with more recent attempts to deliver more sustainable trenching practices using tailored groundwork techniques to allow the safe reuse of site arisings (Assadi Langroudi and Jefferson, 2015). Once the processes had moved on from hand-trimming the base of a trench to accept the pipe barrel, the general procedures for the placement of utilities using the open-cut method involved excavation of a trench, placement of the bedding material, placement of the pipe(s), backfilling the excavated material around and above the pipe, compacting the backfill and surface reinstatement (Ariaratnam et al., 2013).

The direct economic costs of this activity are straightforward to establish. For example, Hunt et al. (2014) assumed an open-cut trenching method in an urban (developed) area to model the

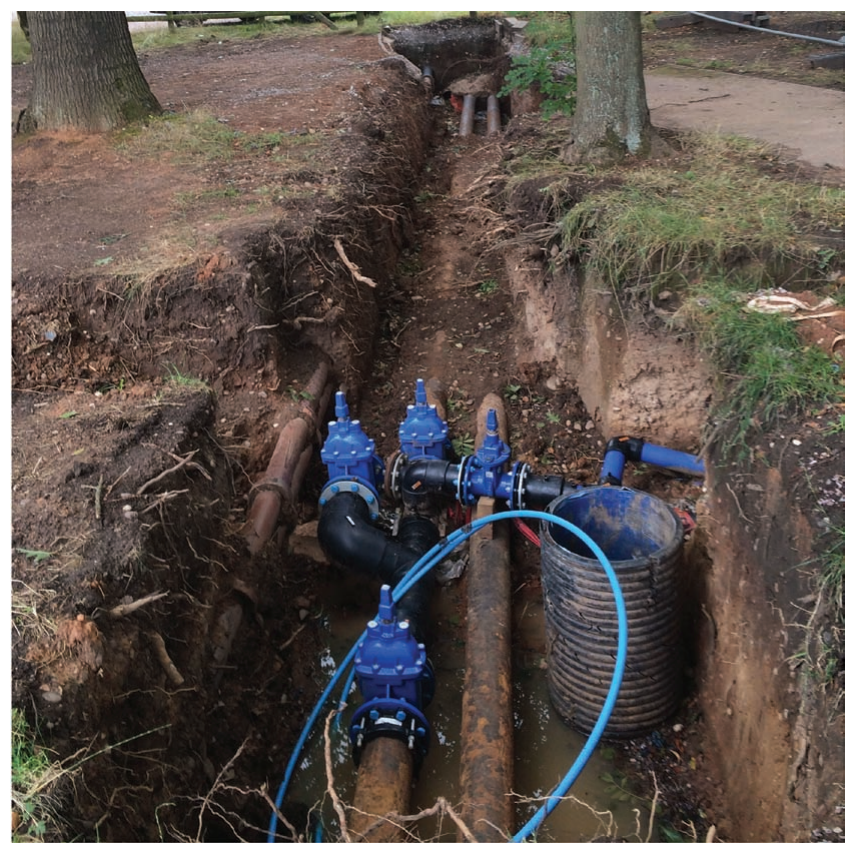

Figure 1. Old and new utilities pipelines in an exposed trench in Birmingham, UK economic costs of utility placement using this engineering process. Because of the relatively simple method of placement, a wide variety of pipe/cable diameters can be installed using the open-cut technique. Several utility sizes, specifically including diameters of 100, 150, 200 and $300 \mathrm{~mm}$, were assumed to be placed under a footway at a shallow depth. It was assumed that a layer of bitumen macadam (including a bound base course and contaminated sub-base) is removed (as part of the excavation process) and sent to landfill. Moreover, excess soft material (equivalent to the volume of pipes) is transferred to landfill. The remaining soft soil material is excavated and subsequently reinstated as backfill. Surface reinstatement is assumed to be carried out using a hardcore sub-base, which is overlain by a dense bitumen macadam base, binder and surface course followed by final surface preparation operations. Hunt et al. (2014) then demonstrated where the economic tipping point between the open-cut trenching technique and MUTs occurs. More sensitivity analyses were carried out on how the economic tipping points might be influenced by the type of utility, pipe density, pipe diameter, number of excavations and reinstatements avoided, location of the infrastructure (undeveloped, suburban and urban) and the type of MUTs.

\subsection{Trenchless technologies}

TTs refer to a wide range of techniques for subsurface construction when installing or rehabilitating buried utility infrastructures and vary in scale upwards to small-diameter tunnels. TTs also cover various techniques of online replacement and renovation of existing pipes, ducts and cables (Najafi, 2005). TTs, which require either minimal (access pits) or no trench excavation, include (but are by no means limited to) techniques such as pipe jacking, microtunnelling (e.g. pilot tube and vacuum microtunnelling), auger boring, horizontal directional drilling (HDD), guided drilling, moling, pipe bursting and pipe ramming (Milligan and Rogers, 2001). The suitability of these technologies for a particular project depends on site conditions, project specifications and installation procedures (Ariaratnam et al., 2013). The main advantage of TTs is the minimal disruption to surface infrastructure (rails, roads and footways), traffic, businesses and society in general. However, as argued above, a comprehensive account of the reduction in adverse consequences relative to open-cut techniques is needed to be set against the cost of the works in order for decision-making between the two to be properly informed. More generally, what is required is a comprehensive account of all costs (including adverse impacts) set against a comprehensive account of all the benefits that could be realised by a proposed project or scheme, for each alternative set of construction processes - only then can the most sustainable choices be accurately judged.

\subsection{Multi-utility tunnels}

MUTs provide an alternative way of placing utilities below ground and one that is both open-ended and more easily smart. By definition, MUTs are conduits that house more than one utility and have been constructed in the form of flush-fitting, shallow 
and deep tunnels (Figure 2). Their obvious primary advantage is that utility pipes and cables can be added or removed without disruption to the other subsurface utilities or the surface and yet, with rapidly growing interest in the use of sensors to monitor infrastructure performance, ready access to pipes and cables to retrofit sensors, and then act on their intelligence, is equally attractive. MUTs are given different names in different countries: 'utilidors' in the USA, 'common service tunnels' in Singapore, 'common utility tunnels' in Malaysia, 'common utility enclosures' in Hong Kong, 'common utility ducts' in Taiwan and 'les galleries multireseaux' in France (Rogers and Hunt, 2006).

MUTs have been utilised in the UK and other countries for over 100 years. For example, an MUT with man access containing foul water and drinking water was introduced in London in 1866 (Cano-Hurtado and Canto-Perello, 1999) and is still in use (Laistner, 1995). The acceptance and use of MUTs are seen in locations where a utility infrastructure is independently owned and operated, such as university campuses, hospitals, recreation parks, military bases and nuclear power plants (Rogers and Hunt, 2006), with examples at Seattle University, the University of Birmingham (Hunt et al., 2012) and Walt Disney World Underground (Pike, 2005). However, they have been also used in Singapore, Taiwan, Malaysia and Hong Kong.

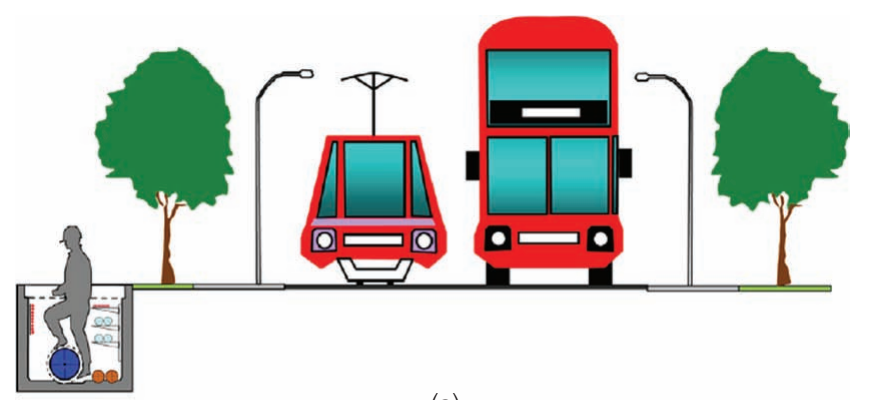

(a)

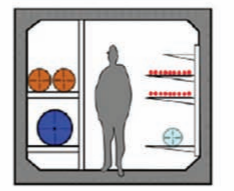

(b)

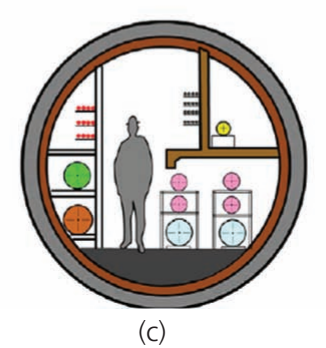

Figure 2. Different types of MUTs: (a) flush-fitting; (b) shallow; (c) deep (Hunt et al., 2014)
There are generally three types of MUT: searchable (Figure 3(a)), visitable (Figure 2(b)) and compartmentalised (Figure 3(b)). Searchable tunnels can be accessed if a lid is removed, whereas visitable MUTs allow complete man entry. Some MUTs, like the one in Helsinki, even allow vehicles to enter for the purpose of maintenance and repairs (Sterling et al., 2012). Searchable MUTs at the University of Birmingham contain various pipelines (steam, heating, hot and cold water) and cables (high-voltage and low-voltage power, data and telecommunications lines) but no gas pipes, as gas is considered a potential explosive mix when combined with electricity (Hunt et al., 2014). On the other hand, compartmentalised MUTs such as those constructed in Japan, Singapore and Malaysia (Adnan and Heng, 2003) house all types of utilities as they provide a barrier between utilities (each utility type in a separate compartment) to prevent potential hazards. Improved quality of placement (with respect to pipe and cable integrity), easy access to maintain and replace utilities, ease of location and leak detection (embedment of sensors within MUTs enhances this capability) and allowing for future additions - delivering a flexible and adaptable infrastructure system - are the main advantages of MUTs and, given that these advantages accrue in the long-term, they represent more sustainable and resilient solutions to the problems associated with utility service provision in the context of built form densification and growing demand.

\section{Sustainability costing tools and evaluation methods}

There is a wide range of sustainability assessment tools and methodologies for infrastructure engineering projects, making it far from straightforward to choose a suitable tool for use in a particular streetworks project. Examples include: Greenlites, Greenroads, I-Last and Building Environmentally and Economically Sustainable Transportation Infrastructure Highways (BE ${ }^{2} \mathrm{ST}$-in-Highways) for transport infrastructure; the State-Building Assessment Tool (SBAT), German Sustainable Building Council (DGNB), Building Research Establishment Environmental Assessment Method (Breeam) and Leadership in Energy and Environmental Design (Leed) for buildings; and EnvISIon, the Halcrow Sustainability Toolkit and Rating System (Halstar), Civil Engineering Environmental Quality Assessment and Award Scheme (Ceequal) and Sustainable Project Appraisal Routine $\left(\mathrm{SPe}_{\mathrm{AR}}{ }^{\circledR}\right)$ for use in all civil infrastructure projects. These are described by Clevenger et al. (2013), Gibberd (2008), Poston et al. (2010), Shaw et al. (2012), Pearce et al. (2012) and Venables et al. (2005). Other recently developed sustainability assessment systems for use in the construction industry in different countries around the world include Estidama in the UAE (ADUPC, 2017), the Qatar Sustainability Assessment System/ Global Sustainability Assessment System in Qatar (Gord, 2017) and Athena in Canada (ASMI, 2017).

In order to select the most appropriate tool or evaluation procedure to be used for streetworks sustainability costing, and ultimately to develop a holistic assessment framework, the many currently available tools and assessment methods have been 


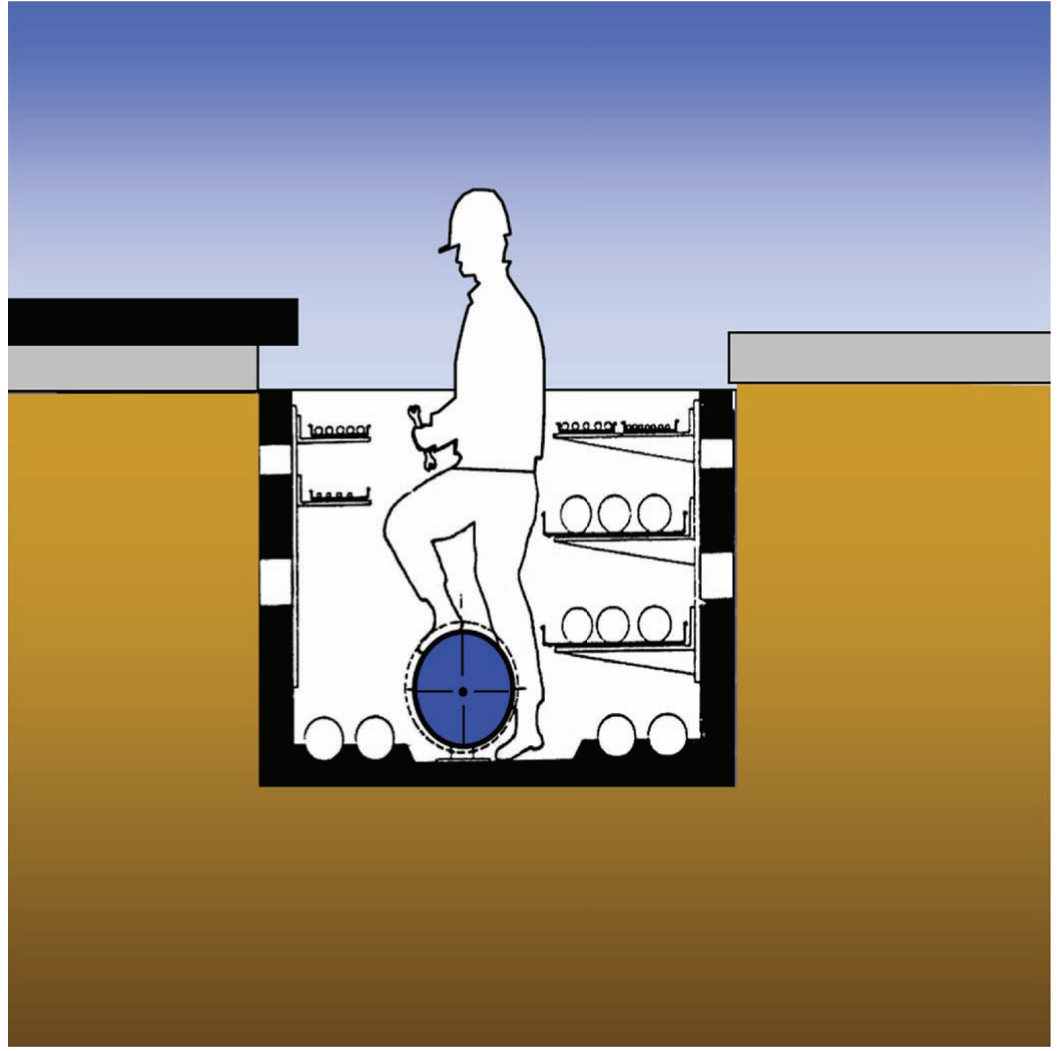

(a)

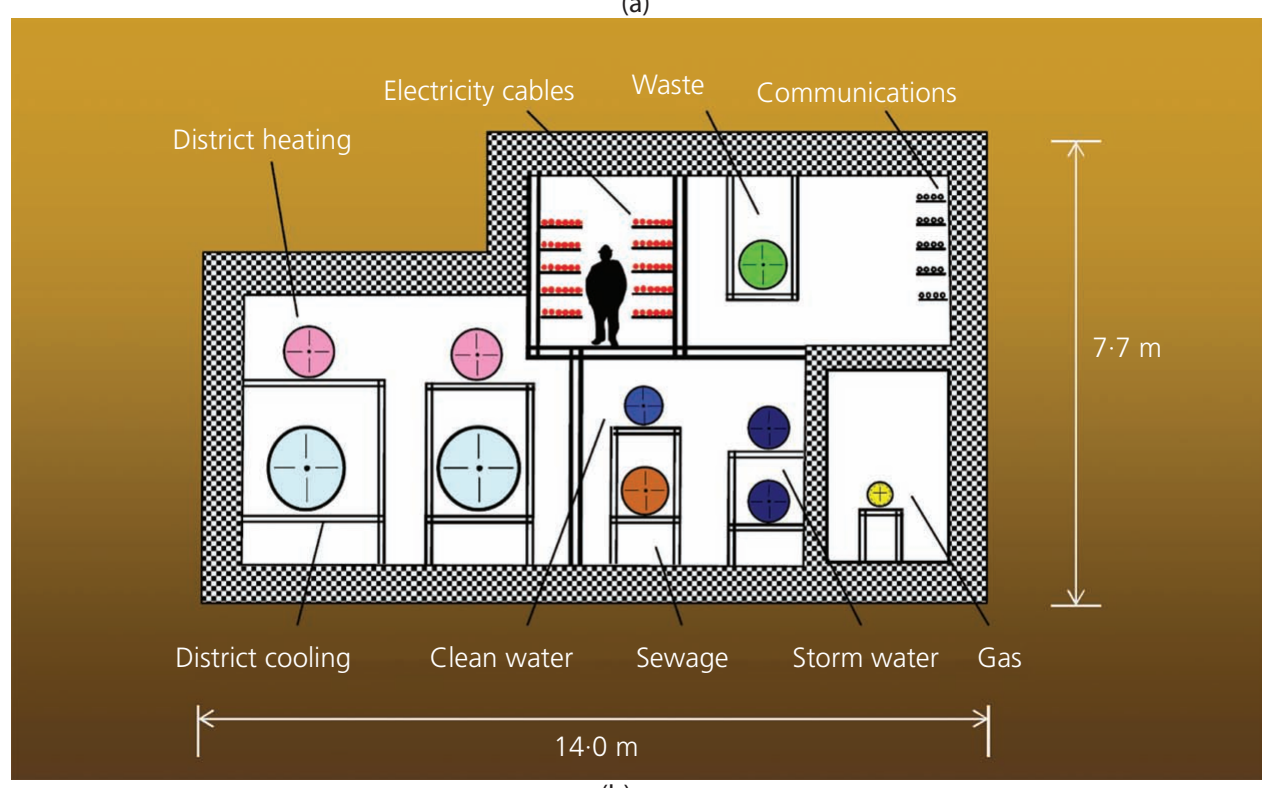

(b)

Figure 3. (a) Searchable MUT (adapted from Canto-Perello and Curiel-Esparza (2001)); (b) compartmentalised MUT (adapted from Rogers and Hunt (2006))

reviewed. Life cycle analysis (LCA), whole-life costing (WLC) and building rating systems (BRSs) were included in this review as three important generic assessment methods. As a result of a survey of practitioners, some 40 tools and assessment frameworks were identified for assessing engineering sustainability. Many were designed for other engineering disciplines or specifically for other civil engineering projects such as buildings (e.g. Breeam and Leed), and hence, they are difficult to apply to streetworks projects. The reviewing process identified their principles in relation to, and established their applicability for, streetworks and 
then determined what was necessary to customise them, where possible, to address utility streetworks. As no single tool proved suitable for a comprehensive sustainability costing of streetworks, the review then considered which of the potential shortlisted tools/methods could be used in combination to develop a novel, holistic assessment framework and ultimately a sustainability costing model. As a result of this process, three sustainability assessment tools were selected for detailed investigation Ceequal, Halstar and SPeAR ${ }^{\circledR}$ - these being toolkits designed to be applied to almost all civil engineering projects.

For each tool/method, the procedure is briefly described along with its advantages and disadvantages in relation to utility infrastructure and streetworks. Moreover, the stage(s) of a project when the tool could be used are identified, and examples of its use, where available, are provided.

\subsection{Life cycle analysis}

LCA tools are primarily used to calculate the environmental impacts, throughout their life cycle, of different alternatives for a product, project or service and are generally used in the design process (Petus, 2005). The methodology for the LCA approach is defined in a number of International Organization for Standardization (ISO) standards - for example, ISO 14040:2006 (Azapagic et al., 2004; ISO, 2006). The LCA method applies a systems approach and can be used for environmental risk management, strategic decision-making and policy assessment and can be applied throughout the life cycle of a project. The Danish LCA tool for buildings, Building Environmental Assessment Tool (Beat) (Petersen, 2002), is an example of a commercial LCA tool in the building sector. Orware is an LCAbased tool for waste management (Eriksson et al., 2002). The principles underpinning the LCA method have been used in urban water provision (Stokes and Horvath, 2010), heavy construction (Ries et al., 2010) and bridge analysis and design (Kendall et al., 2008). LCA is also the basis for some well-established sustainability assessment tools such as Arup's SPeAR ${ }^{\circledR}$, Breeam, the Green Guide to Specification (BRE, 2009) and Envest2, which is a combination of LCA and WLC (BRE, 2015). Other commercial software packages include Gabi (Spatari et al., 2001) and SimaPro (Goedkoop et al., 2008), both of which are LCA tools. Furthermore, the Inventory of Carbon and Energy (ICE) produced at the University of Bath (Hammond and Jones, 2008) is an open-access and reliable database of embodied energy and carbon dioxide for construction materials in the UK that could be used in life cycle assessments for almost any type of construction project, including streetworks.

LCA tools normally require large amounts of detailed and up-to-date data to be input on products and processes for the environmental analyses and calculations within a particular project; therefore, the process can take considerable effort and be very time consuming. This method cannot also easily deal with social impacts and issues associated with society, such as noise, dust and vibration problems (Ainger and Fenner, 2014). Other major issues regarding the LCA methodologies include spatial variation, local environmental conditions, data quality (accuracy) and data availability (Reap et al., 2008).

\subsection{Whole-life cost accounting}

WLC techniques assess the total cost of projects over a project's lifetime, from inception to demolition. Although these costs are economic costs, environmental impacts associated with the project are taken into account. Sometimes referred to as life cycle cost analysis (LCCA), WLC is particularly useful when different project alternatives with approximately the same performance criteria but different costs (throughout the project lifetime, including initial and operating costs) need to be compared to select the one with the highest benefits and the lowest whole-life cost. There are mathematical models for WLC, a summary of which is provided by Kishk et al. (2003). In WLC, many models are based on the concept of net present value, which is defined as the sum of the money required for investment today to meet all future financial needs during the lifetime of the project. Although cost-benefit analysis (CBA), WLC and LCCA are usually simple and easy, if time consuming, to apply, these tools are often used by technical experts and therefore require greater knowledge, understanding and transparency in the assessment procedure.

WLC can be applied to many different kinds of infrastructure projects, including sewerage and potable water services (Savic et al., 2008), trunk sewers as municipal infrastructure (Rahman and Vanier, 2004) and bridges (Ryall, 2001). However, as pointed out in a recent appraisal of the application of life cycle costing within the UK construction industry (Olubodun et al., 2010), problems of understanding of the techniques and lack of a standardised methodology are considered as the key factors militating against the wider implementation of this method. Moreover, while WLC tools take into account the impacts of projects on society in general, they often do not take into consideration who pays for the costs/impacts and who enjoys the benefits (Petus, 2005).

\subsection{Building rating systems and civil engineering award schemes}

BRSs are assessment tools to evaluate and quantify value judgements and to assess different project options, often using multi-criteria decision analysis (Kiker et al., 2005). These rating systems are multi-dimensional, criteria-based assessment tools that are often verified by a third party. They normally include a green building certification scheme. The most notable ones are Breeam in the UK and Leed in the USA, which were both introduced in the 1990s, and the International Green Building Tool, which is more recent (Bernier et al., 2010).

Ainger and Fenner (2014) noted that some assessment tools, including Breeam (UK) (BRE, 2011), Leed (USA) (USGBC, 2016), Building Environmental Performance Assessment Criteria (Bepac) (Canada) (Cole, 1994) and Hong Kong Building Environmental Assessment Method (HK-Beam) (Hong Kong) 
(Yik et al., 1998), do not reflect the fundamental principles of a wide range of projects because they do not consider the economic (financial) aspects of projects within the assessment framework. Another issue with BRSs is that they can be applied only to the building construction sector, and cannot be implemented in other infrastructure categories, although tools like Ceequal (Ceequal, 2009) have been developed to bridge this gap. Furthermore, while it is difficult and complex to define the boundaries for national, regional, social and cultural variations (Ding, 2008), building rating tools do not usually take into account these variations as they are often developed for local use. Kohler (1999) notes some of these variations, including variations in climatic conditions, income level, building materials and techniques and consideration of historic value.

\subsection{Ceequal}

Ceequal is an evidence-based assessment and award scheme designed by a team led by the Institution of Civil Engineers in the UK in 2003 to ensure and demonstrate the commitment of the civil engineering industry to environmental quality and social performance (Ceequal, 2009). It was initially set up to provide a scheme for the environmental assessment of civil engineering projects. Ceequal is the result of a project that was called 'a civil engineering equivalent of BREEAM' (Venables et al., 2005: p. A-1598). It is applicable to all civil engineering projects (including roads, railways, airports, coast, canal and river works, water supply and treatment, power stations, retail and business parks) rather than to a specific type of project (building) as in Breeam. A self-assessment is carried out by a trained Ceequal assessor to score the project in question. This is then reviewed and validated by an external verifier appointed by Ceequal. Finally, the result and award recommendation is checked and ratified by Ceequal.

Ceequal is based on a scoring framework of issues and major design considerations, with 180 questions related to 12 areas of environmental and social concern. Each of the 12 areas is weighted by a percentage as the final score. The performance based on the final score is then rated as pass, good, very good or excellent. It is possible to strike out the questions that are not relevant to a project so that Ceequal is matched to each project only by the relevant questions.

Although Ceequal can be applied to many civil engineering projects, Hayes et al. (2012) demonstrated that its generality results in a large number of criteria, which in turn makes using this tool a time-consuming process. Holt et al. (2010) indicated that, in reality, using Ceequal is predominately environmentally focused; hence, it fails to provide the comprehensive and holistic approach needed to assess fully the sustainability of infrastructure projects. However, there are some criteria within the Ceequal assessment, such as nuisance to neighbours and energy and material use, which can be regarded as social and economic (financial) aspects, respectively. Still, the system does not provide a balanced approach for the assessment between the three pillars of sustainability. More assessment criteria and indicators are required to be developed and added to Ceequal, both to make it a balanced method and to tailor it for specific contexts such as streetworks projects.

Another important drawback for schemes such as Ceequal, Breeam and Leed is their awarding focus, which does not truly encourage different stakeholders involved in a project to improve sustainability, but to treat such assessment solely as a checklist to tick as many boxes as possible to achieve the award.

\subsection{Halstar}

Halstar is another sustainability assessment tool which is based on a systems model of sustainable development (Pearce et al., 2012) that represents a balance between a range of needs (which are called capitals), for a nested system of stakeholders, during the lifetime of a project. It aims to ensure that sustainability is a source of added value to projects rather than just being an add-on to the development process (Pearce et al., 2012). Moreover, the Halstar sustainability wheel (Figure 4) encompasses definitions distilled from over 400 approaches, including but not limited to assessment methods, indicator sets, legislation, planning policies, corporate social responsibility reports and the needs and requirements of the key stakeholders.

In addition, the tool contains a database that includes 840 subissues, approximately 4200 qualitative criteria and 2000 indicators. While the concept of systems thinking and the systems model of sustainability provide a strong background for Halstar to be capable of connecting high-level policy with project-level practice and to provide a comprehensive context-driven appraisal of almost all the key factors affecting the sustainability of a project (Pearce et al., 2012), it seems to be a complicated and time-consuming process to apply this system to a particular project with limited boundary conditions and specific requirements. This might also lead to what Holt et al. (2010) refer to as 'tool fatigue', which, however, could also be true for the development of an entirely new assessment method.

\section{6 $\mathrm{SPeAR}^{\circledR}$}

$\mathrm{SPeAR}^{\circledR}$ was originally developed by the international consulting practice Arup in 2001 (Arup, 2016). It evaluates projects, processes or products using a four-way bottom-line approach covering economic, social, environmental and natural resources criteria. SPeAR ${ }^{\circledR}$ contains a set of core sectors and indicators that have been derived from different sources of literature on sustainability. It has been designed to make sustainability more meaningful to a wider range of stakeholders. This tool reflects international best practice and is founded on a number of sustainability indicator sets, including the UK government's set of sustainability indicators, the UN indicators for sustainable development, the UN Environment Programme indicators and the Global Reporting Initiative G3 indicators (Braithwaite, 2007). The software used to undertake the assessment is, however, able to be modified to include new indicators that reflect the scope 


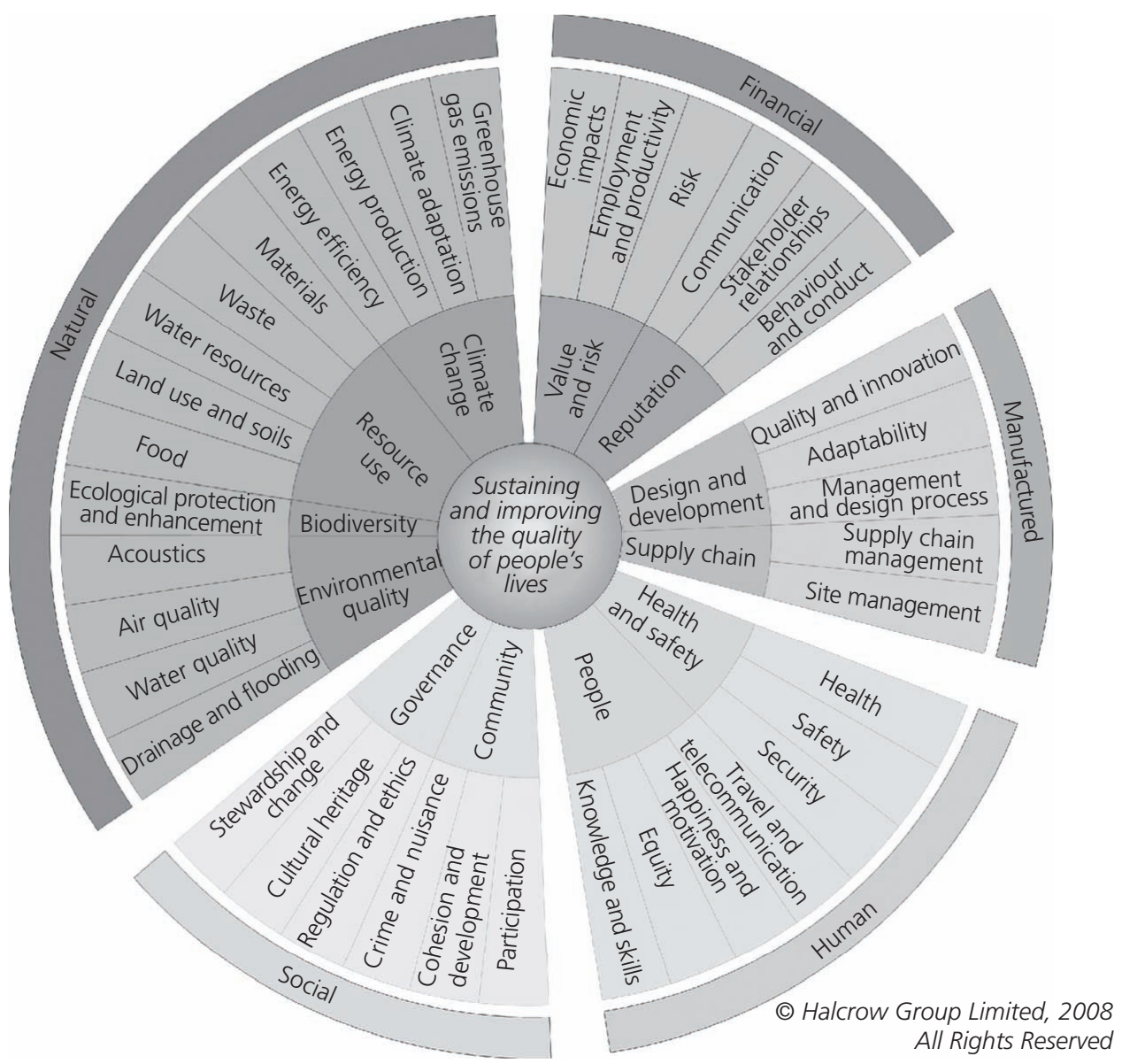

Figure 4. Extract of the Halstar sustainability wheel (Pearce et al., 2012)

and context of a particular project and hence create a bespoke assessment (Venables et al., 2005).

The SPeAR ${ }^{\circledR}$ diagram indicates the performance of indicators by shading in a segment on the face. The closer a segment is to the centre of the diagram, the stronger it is in terms of sustainability; conversely, the further away it is from the centre of the diagram, the weaker the segment is in terms of sustainability (Figure 5).

Behind the $\mathrm{SPeAR}^{\circledR}$ rose diagram is a series of detailed worksheets, with more than 120 economic, social, environmental and natural resource performance subindicators (Braithwaite, 2007). The performance of each indicator is set against a scale of optimum and worst cases. The optimum or best case represents cutting-edge approaches that are benchmarked against appropriate expertise; a score of zero (representing the midpoint on a positive to negative scale, or the middle ring in the diagram in Figure 5) equates to the current best practice, and the worst case represents bare compliance with legislation (Holt et al., 2010). The aim is for the diagram to provide a unique profile of predicted performance, highlighting both sustainability strengths and weaknesses.
One of the key strengths of $\mathrm{SPeAR}^{\circledR}$ is its flexibility. Unlike Breeam and Ceequal, in which the relative importance of the sections is weighted, the sections of $\operatorname{SPeAR}^{\circledR}$ and the corresponding indicators and subindicators are not weighted (Venables et al., 2005). Moreover, it is not reward-driven and therefore does not consist of in-built bias (Holt et al., 2010). Pearce et al. (2012) argued that because $\operatorname{SPeAR}{ }^{\circledR}$ does not encompass all the aspects and issues that might be important in any particular context, different versions of this tool have been developed for different contexts. Examples include GeoSPeAR, developed by Holt et al. (2010) for use in geotechnical engineering projects due to a lack of specific methods to assess sustainability in this field, an adaptation of SPeAR ${ }^{\circledR}$ for environmental geotechnics by Jefferson et al. (2007), who took a similar approach, and the development of Aspire (EAP and Arup, 2009) for poverty reduction projects.

Although SPeAR ${ }^{\circledR}$ is a holistic, flexible and easy-to-use tool for sustainability assessment of different civil engineering projects, the oversimplification of the scoring system increases the potential of the tool to be misused. Furthermore, a set of sustainability criteria and indicator systems does not exist within the tool to address the complex issue of streetworks projects, and this is mainly due to 
Sustainability assessment for urban underground utility infrastructure projects

Hojjati, Jefferson, Metje and Rogers

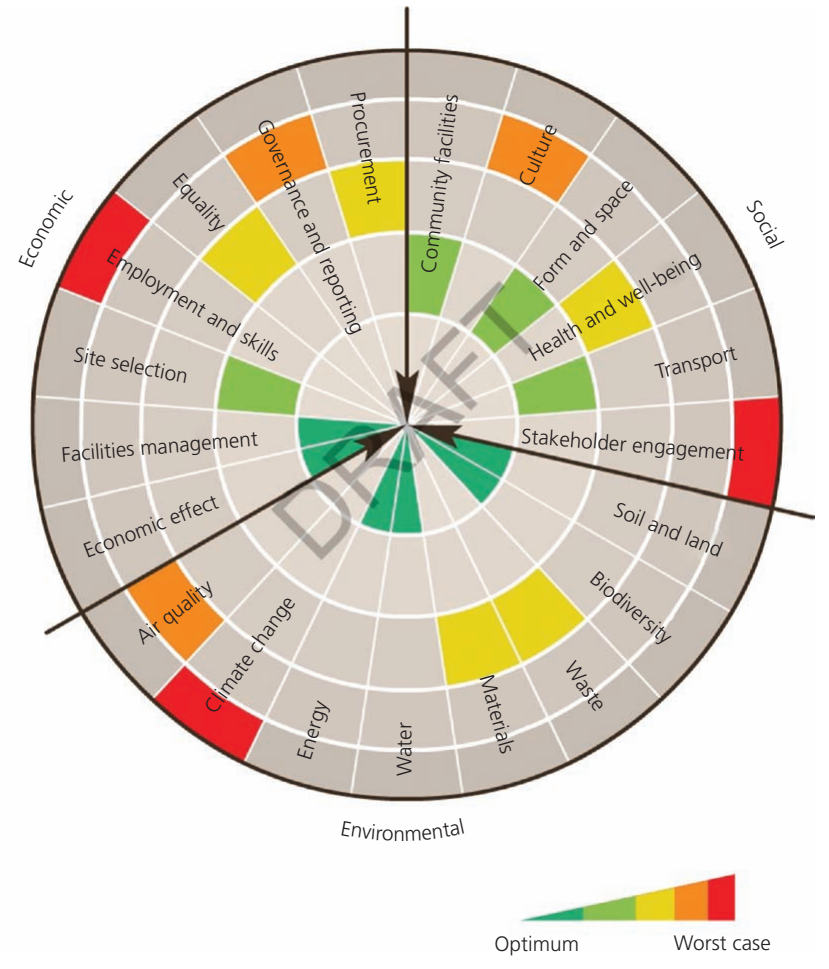

Figure 5. Extract of the Arup SPeAR ${ }^{\circledR}$ diagram template (Arup, 2016)

the very broad and generic indicator sets available in the SPeAR ${ }^{\circledR}$ system. Therefore, adding new indicators or adjustment of the exiting indicator sets specific to the context of streetworks could be regarded as part of the potential solution for the development of a sustainability assessment framework for streetworks.

\section{Discussion: towards a comprehensive streetworks sustainability assessment framework (SSAF)}

A key challenge in determining the true total cost of utility streetworks is how social and environmental aspects are assessed. Estimates of these costs are often driven by a subset of stakeholders (whose agendas vary), while certain social and environmental impacts are simply not possible to cost with any reliability given the qualitative nature of the impact being assessed - for example, social amenity, visual intrusion or loss of space. Although the UK Water Industry Research's (UKWIR's) commissioned report on the topic (McMahon et al., 2006) opened the debate, it acknowledged that it stopped far short of being comprehensive, and thus at present, no methodology is available to evaluate the total cost of streetworks. Hayes (2013) has taken the debate further, but has also stopped short as a result of a lack of adequately comprehensive data sets on which to base rigorous judgements.

Other examples of previous research on this specific topic include the studies of Rogers and Hunt (2006), who created a credit-based costing model for the sustainability assessment of open-cut trenching compared with MUTs and TTs; Hunt et al. (2014), who proposed a method to establish direct economic costs of streetworks; Jung (2012), who performed a CBA for subsurface utility engineering; and Ariaratnam et al. (2013), who quantified a sustainability index for urban underground infrastructure (by comparing trenching with three TT techniques using the weighted sum method).

More generally, a number of approaches such as CBA and LCA have been tried, but none has been successful due to the complex and variable nature of dealing with all three cost elements in the complex context of the impacts caused by streetworks in cities (Hayes et al., 2012). Moreover, the application of these approaches has been questioned for complex cases as they often cannot be used sufficiently realistically or transparently, leading to uncertainty in the outcomes.

Therefore, this paper recommends the development of a sustainability evaluation methodology for utility streetworks that can be used to judge alternative intervention approaches, whether based on trenching, trenchless methods (e.g. keyhole surgery, access by way of vacuum excavation holes, moling, HDD or microtunnelling, pipe bursting/splitting/lining, various methods of pipe relining or pipe repairs using small trial pits), MUTs or some other method, or provide sufficient information to justify a do-nothing option. The assessment tool should determine the total impact (which includes costs) of streetworks from where a value judgement can be made within a broader asset management framework (Hojjati et al., 2016), learning from the most appropriate features of the assessment methodologies that have been developed previously and have been reviewed here (see Table 1 for a summary).

Basu et al. (2014) provided a review of current sustainability studies in geotechnical engineering, which included studies on the development of sustainability assessment tools. The tools were categorised into qualitative and quantitative methods in terms of their methodology (Figure 6).

The results of this review and categorisation can also be applied to utility infrastructure projects. Due to the nature of utility streetworks and the costs and impacts associated with such projects, a combination of qualitative and quantitative tools is proposed for the development of a total sustainability evaluation methodology, and this work is underway by way of the 'Assessing the Underworld' project (Rogers, 2015; Rogers et al., 2012). Sets of indicators specifically designed for utility streetworks have been identified and are being validated by a wide group of experts and stakeholders. As Basu et al. (2014) indicate, qualitative tools such as colour-coded charts and traffic light systems (i.e. apportioning red, amber and green to highlight where indicators are acceptable or on need of improvement) are useful for the assessment of non-monetary (qualitative) indicators within the assessment frameworks. Examples of non-monetary indicators include, but are not limited to, disruption (due to streetworks) to the local community (visual intrusion, noise, vibration, smell, compromised pedestrian access etc.) and disruption to businesses. 
Table 1. Summary of advantages and disadvantages of existing main sustainability assessment methods

\begin{tabular}{|c|c|c|c|c|}
\hline $\begin{array}{l}\text { Method } \\
\text { (technique) }\end{array}$ & Application & & Advantages & Disadvantages \\
\hline LCA & $\begin{array}{l}\text { All civil infrastructure } \\
\text { and buildings }\end{array}$ & - & $\begin{array}{l}\text { Applicable throughout the life cycle of projects } \\
\text { Applicable for environmental risk management and } \\
\text { strategic decision-making }\end{array}$ & $\begin{array}{l}\text { Large data input requirement } \\
\text { Very time-consuming process } \\
\text { Lack of social impacts consideration }\end{array}$ \\
\hline WLC & $\begin{array}{l}\text { All civil infrastructure } \\
\text { and buildings }\end{array}$ & - & $\begin{array}{l}\text { Applicable throughout the life cycle of projects } \\
\text { Useful for appraisal of future financial needs of } \\
\text { projects }\end{array}$ & $\begin{array}{l}\text { Requires considerable knowledge and } \\
\text { expertise to use } \\
\text { Lack of standardised methodology }\end{array}$ \\
\hline BRSS & $\begin{array}{l}\text { Mainly applicable to } \\
\text { buildings }\end{array}$ & घ & $\begin{array}{l}\text { Multi-dimensional assessment often verified by a } \\
\text { third party } \\
\text { Normally includes a green building certification } \\
\text { scheme }\end{array}$ & $\begin{array}{l}\text { Can be applied only to building } \\
\text { construction sector } \\
\text { Does not consider the economic (financial) } \\
\text { aspects of projects }\end{array}$ \\
\hline Ceequal & $\begin{array}{l}\text { All civil infrastructure } \\
\text { and buildings }\end{array}$ & 口 & $\begin{array}{l}\text { Evidence-based assessment } \\
\text { Assessment by trained assessor as well as review } \\
\text { and validation by an external verifier }\end{array}$ & $\begin{array}{l}\text { Award-focused } \\
\text { Lack of a balanced holistic approach } \\
\text { (emphasis on environmental } \\
\text { considerations) }\end{array}$ \\
\hline Halstar & $\begin{array}{l}\text { All civil infrastructure } \\
\text { and buildings }\end{array}$ & - & $\begin{array}{l}\text { Based on systems thinking approach } \\
\text { A comprehensive database of criteria and } \\
\text { indicators }\end{array}$ & $\begin{array}{l}\text { Complicated, time-consuming process } \\
\text { Potential for tool fatigue }\end{array}$ \\
\hline $\operatorname{SPeAR}{ }^{\circledR}$ & $\begin{array}{l}\text { All civil infrastructure } \\
\text { and buildings }\end{array}$ & a & $\begin{array}{l}\text { Flexibility and ability to be modified } \\
\text { Not reward-driven } \\
\text { No weighting for indicators/criteria }\end{array}$ & $\begin{array}{l}\text { Oversimplified scoring system } \\
\text { Very broad and generic indicator sets }\end{array}$ \\
\hline
\end{tabular}

Numerical tools will be used to assess the quantitative costs and impacts (mostly monetary costs) of utility streetworks carried out using either traditional trenching or alternative working practices (such as TTs and MUTs). Social and environmental accounting using WLC techniques will be utilised to capture the monetary impacts of streetworks, such as delay costs to road users (personal time, fuel consumption, additional wear and tear costs of vehicles,

Studies on development of sustainability assessment tools

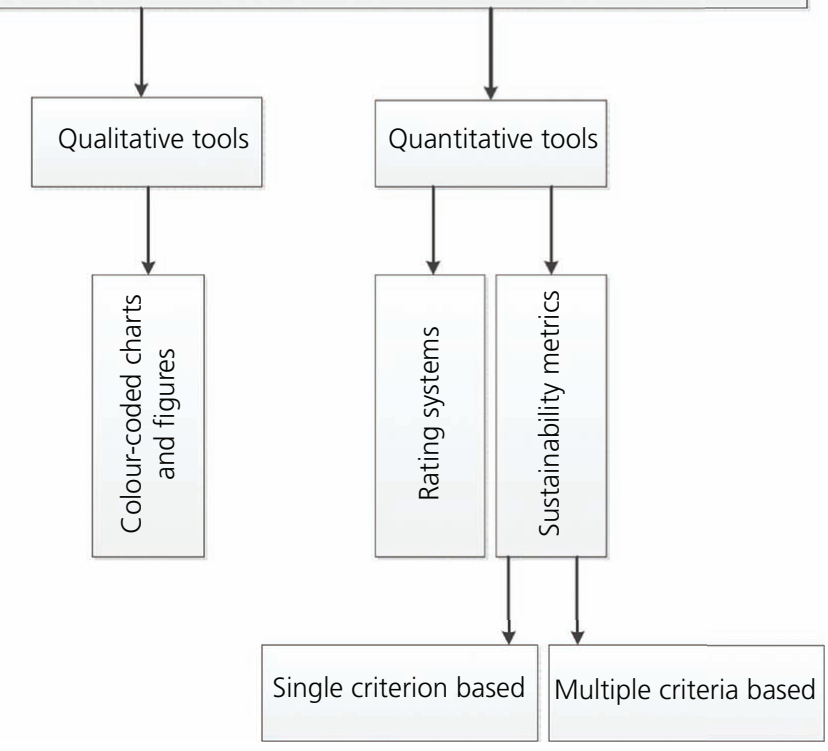

Figure 6. Summary of studies on sustainability assessment tools (adapted from Basu et al. (2014)). C 2008 Canadian Science Publishing or its licensors. Reproduced with permission accidents etc.). The results of each of the assessments using a mix of qualitative and quantitative tools will be integrated in a multi-criteria model based on the analytic hierarchy process (AHP) approach to achieve a final sustainability index for each alternative utility streetworks method. This will ultimately help the decision-making process, and the results of this sustainability assessment will feed into an overarching decision-support system (DSS), which itself will form the basis of an integrated performance model of city infrastructures.

\section{Conclusions}

Through their impacts on the environment and society, and their critical role within urban environments, utility infrastructure systems and the resources they supply play a pivotal role in driving the sustainable development of cities. However, utility installation, maintenance and upgrades are costly activities in terms of the economic costs (both direct and indirect) to, as well as social and environmental impacts they have on, local and global economies. There is a need for a bespoke sustainability assessment tool for utility streetworks that can capture the costs and impacts of these activities from a holistic sustainability viewpoint - that is, a tool that can consider the full economic, as well as social and environmental, costs of these works.

With reference to the concept of sustainable development and alternative engineering practices for utility streetworks, this paper has reviewed existing sustainability assessment tools and frameworks with a view to their applicability to streetworks projects. None provides a sufficiently specific and comprehensive assessment to provide the necessary evidence base for effective decision-making when considering traditional (open-cut) or alternative (TTs, MUTs) techniques for the provision of subsurface utility infrastructures. Without such an evidence base, the 'business 
case for change' is compromised and practices that are widely criticised as unsustainable are routinely adopted.

It is evident that sets of indicators specifically designed for utility streetworks are required and that qualitative tools such as colour-coded charts (e.g. using traffic light systems) are helpful for the assessment of non-monetary indicators. These need to be supported by numerical tools to assess the quantitative costs and impacts of utility streetworks carried out using different working practices, augmented by social and environmental accounting using WLC techniques. It is recommended that the results of these assessments should be integrated in a multicriteria model based on the AHP approach to achieve a final sustainability index for each alternative utility streetworks method and that the outcomes should be fed into an overarching DSS, which itself will form the basis of an integrated performance model of city infrastructures. This will inform decision makers (asset owners, consultants and contractors) engaged in utility streetworks projects of the likely outcomes of their decisions both in terms of economic costs and the impacts on society and the environment as a whole, thus delivering a truly balanced 'sustainability impacts perspective'. It will also provide a basis to support investment decisions for utility infrastructure projects in cities, a crucial element in the judgement of alternative business models, which itself leads to a realisation of the value of a particular utility streetworks option to different stakeholders of a project.

\section{Acknowledgements}

The authors gratefully acknowledge the financial support provided by the UK's Engineering and Physical Sciences Research Council under the Assessing the Underworld (ATU) (EP/K021699) and i-Build: Infrastructure BUsiness models, valuation and Innovation for Local Delivery (EP/K012398) project grants.

\section{REFERENCES}

Adnan S and Heng T (2003) Common utility tunnel for utility services at Putrajaya, new administrative centre of Malaysia. Water Supply 3(1-2): 29-34.

ADUPC (Abu Dhabi Urban Planning Council) (2017) http://www.estidama. upc.gov.ae/(accessed 31/01/2017).

Ainger CM and Fenner R (2014) Sustainable Infrastructure: Principles into Practice. ICE Publishing, London, UK.

Ariaratnam ST, Piratla K, Cohen A and Olson M (2013) Quantification of sustainability index for underground utility infrastructure projects. Journal of Construction Engineering and Management 139(12): 31-38, http://dx.doi.org/10.1061/(ASCE)CO.1943-7862.0000763.

Arup (2016) SPeAR (Sustainable Project Appraisal Routine). Arup, London, UK. See http://www.arup.com/Projects/SPeAR.aspx (accessed 28/03/2016).

ASMI (Athena Sustainable Materials Institute) (2017) http://www. athenasmi.org/ (accessed 31/01/2017).

Assadi Langroudi A and Jefferson I (2015) Constraints in using site-won calcareous clayey silt (loam) as fill materials. In Geotechnical Engineering for Infrastructure and Development: Proceedings of the XVI European Conference on Soil Mechanics and Geotechnical Engineering (Winter MG, Smith DM, Eldred PJL and Toll DG (eds)). ICE Publishing, London, UK, pp. 1947-1952.
Azapagic A, Perdan S and Clift R (2004) Sustainable Development in Practice: Case Studies for Engineers and Scientists. Wiley, Chichester, UK

Balance T, Reid S and Chalmers L (2002) Lane Rental Charging: a Way Forward. Stone and Webster Consultants, London, UK

Basu D, Misra A and Puppala AJ (2014) Sustainability and geotechnical engineering: perspectives and review. Canadian Geotechnical Journal 52(1): 96-113, http://dx.doi.org/10.1139/cgj-2013-0120.

Bernier P, Fenner R and Ainger C (2010) Assessing the sustainability merits of retrofitting existing homes. Proceedings of the Institution of Civil Engineers - Engineering Sustainability 163(4): 197-207, http://dx.doi.org/10.1680/ensu.2010.163.4.197.

Braithwaite P (2007) Improving company performance through sustainability assessment. Proceedings of the Institution of Civil Engineers - Engineering Sustainability 160(2): 95-103, http://dx.doi.org/10.1680/ensu.2007.160.2.95.

BRE (Building Research Establishment) (2009) Green Guide to Specification. BRE, Watford, UK. See http://www.bre.co.uk/ greenguide/podpage.jsp?id=2126 (accessed 18/04/2016).

BRE (2011) Building Research Establishment Environmental Assessment Method. Breeam, Reading, UK. See http://www.breeam.org (accessed 19/04/2016).

BRE (2015) Environmental Impact Assessment and Whole Life Cost. BRE, Watford, UK. See http://envest2.bre.co.uk/ (accessed 21/04/2016).

Brundtland GH (1987) Report of the World Commission on Environment and Development: Our Common Future. United Nations, New York, NY, USA.

Cano-Hurtado JJ and Canto-Perello J (1999) Sustainable development of urban underground space for utilities. Tunnelling and Underground Space Technology 14(3): 335-340, http://dx.doi.org/10.1016/S08867798(99)00048-6.

Canto-Perello J and Curiel-Esparza J (2001) Human factors engineering in utility tunnel design. Tunnelling and Underground Space Technology 16(3): 211-215, http://dx.doi.org/10.1016/S0886-7798(01)00041-4.

Ceequal (2009) Civil Engineering Environmental Quality Assessment and Award Scheme. Ceequal, Watford, UK. See http://www.ceequal.co.uk/ (accessed 29/03/2016).

Chambers T, Porritt J and Price-Thomas P (2008) Sustainable Wealth Creation within Environmental Limits. Forum for the Future, London, UK.

Clevenger CM, Ozbek ME and Simpson S (2013) Review of sustainability rating systems used for infrastructure projects. Proceedings of 49th ASC Annual International Conference, San Luis Obispo, CA, USA, pp. $10-13$.

Cole RJ (1994) Building Environmental Performance Assessment Criteria. National Institute of Standards and Technology, Gaithersburg, MD, USA, BEPAC (CONF-9402130-).

Ding GK (2008) Sustainable construction - the role of environmental assessment tools. Journal of Environmental Management 86(3): 451-464, http://dx.doi.org/10.1016/j.jenvman.2006.12.025.

EAP (Engineers against Poverty) and Arup (2009) ASPIRE Research and Development Manual. EAP, London, UK; Arup, London, UK. See http://www.engineersagainstpoverty.org/ (accessed 28/03/2016).

Elghali L, Clift R, Begg K and McLaren S (2008) Decision support methodology for complex contexts. Proceedings of the Institution of Civil Engineers - Engineering Sustainability 161(1): 7-22, http://dx.doi.org/10.1680/ensu.2008.161.1.7.

Eriksson O, Frostell B, Björklund A et al. (2002) ORWARE - a simulation tool for waste management. Resources, Conservation and Recycling 36(4): 287-307, http://dx.doi.org/10.1016/S0921-3449(02)00031-9.

Gibberd J (2008) The sustainable building assessment tool: integrating sustainability into current design and building processes. In Proceedings of World Sustainable Building Conference (Foliente G, Luetzkendorf T, Newton P and Paevere P (eds)). CIB, Melbourne, Australia, pp. 945-950. 
Goedkoop M, De Schryver A and Oele M (2008) Introduction to LCA with SimaPro 7. PRé Consultants, Amersfoort, the Netherlands.

Gord (Gulf Organisation for Research and Development) (2017) http://www.gord.qa/gord-trust (accessed 31/01/2017).

Hammond G and Jones C (2008) Inventory of Carbon and Energy: ICE. Sustainable Energy Research Team, Department of Mechanical Engineering, University of Bath, Bath, UK.

Hayes R (2013) Development of a Sustainability Assessment Methodology for UK Streetworks Projects. PhD thesis, University of Birmingham, Birmingham, UK

Hayes R, Chapman DN, Metje N and Rogers CDF (2012) Sustainability assessment of UK streetworks. Proceedings of the Institution of Civil Engineers - Municipal Engineer 165(4): 193-204, http://dx.doi.org/ 10.1680/muen.12.00004.

Hojjati A, Jefferson I, Metje N and Rogers CDF (2016) Sustainable asset management for utility streetworks. In Transforming the Future of Infrastructure through Smarter Information: Proceedings of the International Conference on Smart Infrastructure and Construction (ICSIC 2016) (Mair RJ, Soga K, Jin Y, Parlikad AL and Schooling JM (eds)). ICE Publishing, London, UK, pp. 669-674.

Holt DGA, Jefferson I, Braithwaite PA and Chapman DN (2010) Embedding sustainability into geotechnics: part A: methodology. Proceedings of the Institution of Civil Engineers - Engineering Sustainability 163(3): 127-135, http://dx.doi.org/10.1680/ensu.2010. 163.3.127.

Hunt DVL, Jefferson I, Drinkwater NK and Rogers CDF (2012) Sustainable utility placement for University campuses. In GeoCongress 2012: State of the Art and Practice in Geotechnical Engineering (Hryciw RD, Athanasopoulos-Zekkos A and Yesiller N (eds)). American Society of Civil Engineers, Reston, VA, USA, Geotechnical Special Publication no. 225, pp. 4309-4318.

Hunt DVL, Nash D and Rogers CDF (2014) Sustainable utility placement via multi-utility tunnels. Tunnelling and Underground Space Technology 39: 15-26, http://dx.doi.org/10.1016/j.tust.2012.02.001.

ISO (International Organization for Standardization) (2006) ISO 14040:2006: Environmental management - life cycle assessment principles and framework. ISO, Geneva, Switzerland.

Jefferson I, Hunt DVL, Birchall CA and Rogers CDF (2007) Sustainability indicators for environmental geotechnics. Proceedings of the Institution of Civil Engineers - Engineering Sustainability 160(2): 57-78, http://dx.doi.org/10.1680/ensu.2007.160.2.57.

Jung YJ (2012) Evaluation of subsurface utility engineering for highway projects: benefit-cost analysis. Tunnelling and Underground Space Technology 27(1): 111-122, http://dx.doi.org/10.1016/j.tust.2011.08. 002.

Keaton JR (2014) Sustainability concepts and some examples common in geotechnical engineering. In Geo-Congress 2014 Technical Papers: GeoCharacterization and Modeling for Sustainability (Abu-Farsakh M, Yu X and Hoyos LR (eds)). American Society of Civil Engineers, Reston, VA, USA, Geotechnical Special Publication no. 234, pp. 3817-3825.

Kendall A, Keoleian GA and Helfand GE (2008) Integrated lifecycle assessment and life-cycle cost analysis model for concrete bridge deck applications. Journal of Infrastructure Systems 14(3): 214-222, http://dx.doi.org/10.1061/(ASCE)1076-0342(2008)14:3 (214).

Kiker GA, Bridges TS, Varghese A, Seager TP and Linkov I (2005) Application of multicriteria decision analysis in environmental decision making. Integrated Environmental Assessment and Management 1(2) 95-108, http://dx.doi.org/10.1897/IEAM_2004a-015.1.

Kishk M, Al-Hajj A, Pollock R et al. (2003) Whole life costing in construction - a state of the art review. RICS Foundation Research Papers 4(18): 1-39.

Kohler N (1999) The relevance of Green Building Challenge: an observer's perspective. Building Research and Information 27(4-5): 309-320, http://dx.doi.org/10.1080/096132199369426.
Kolator R (1998) Economic comparison between conventional trench method and trenchless technology in an urban environment. Proceedings of the 16th International No-Dig, Lausanne, Switzerland, pp. 51-64.

Laistner A (1995) Modern urban utility tunnels. Proceedings of No-Dig International, London, UK, pp. 11-15.

McMahon W, Burtwell M and Evans M (2006) Minimising Street Works Disruption: The Real Costs of Street Works to the Utility Industry and Society. UK Water Industry Research, London, UK.

Milligan GWE and Rogers CDF (2001) Trenchless technology. In Geotechnical and Geoenvironmental Engineering Handbook (Rowe RK (ed.)). Kluwer Academic Publishing, Norwell, MA, USA, pp. 569-592.

Najafi M (2005) Trenchless Technology. McGraw-Hill, New York, NY, USA, pp. 1-21.

Olubodun F, Kangwa J, Oladapo A and Thompson J (2010) An appraisal of the level of application of life cycle costing within the construction industry in the UK. Structural Survey 28(4): 254-265, http://dx.doi. org/10.1108/02630801011070966.

Pearce OJD, Murry NJA and Broyd TW (2012) Halstar: systems engineering for sustainable development. Proceedings of the Institution of Civil Engineers - Engineering Sustainability 165(2): 129-140, http://dx.doi.org/10.1680/ensu.9.00064.

Petersen EH (2002) BEAT 2002 - an LCA based assessment tool for the building industry. Proceedings of the Sustainable Building Conference, Oslo, Norway.

Petus (Practical Evaluation Tools for Urban Sustainability) (2005) Practical Evaluation Tools for Urban Sustainability. Petus, Cardiff, UK. See http://www.petus.eu.com/ (accessed 22/03/2016).

Pike DL (2005) The Walt Disney World Underground. Space and Culture 8(1): 47-65, https://doi.org/10.1177/1206331204269432.

Poston A, Emmanuel R and Thomson C (2010) Developing holistic frameworks for the next generation of sustainability assessment methods for the built environment. In Proceedings of the 26th Annual ARCOM Conference (Egbu C (ed.)). Association of Researchers in Construction Management, Leeds, UK, pp. 1487-1496.

Rahman S and Vanier DJ (2004) Life cycle cost analysis as a decision support tool for managing municipal infrastructure. Building for the Future: The 16th CIB World Building Congress, Rotterdam, the Netherlands.

Reap J, Roman F, Duncan S and Bras B (2008) A survey of unresolved problems in life cycle assessment. International Journal of Life Cycle Assessment 13(5): 374-388, http://dx.doi.org/10.1007/s11367-0080009-9.

Ries R, Velayutham S and Chang Y (2010) Life cycle assessment modeling of heavy construction activities. In Construction Research Congress 2010: Innovation for Reshaping Construction Practice (Ruwanpura J, Mohamed Y and Lee SH (eds)). American Society of Civil Engineers, Reston, VA, USA, pp. 1467-1476.

Rogers CDF (2015) Assessing the underworld - remote sensing to support smart and liveable cities. Proceedings of 8 th International Workshop on Advanced Ground Penetrating Radar (IWAGPR 2015), Florence, Italy.

Rogers CDF and Hunt DVL (2006) Sustainable utility infrastructure via multi-utility tunnels. Proceedings of the Canadian Society of Civil Engineering 2006 Conference, towards a Sustainable Future, Calgary, Canada, pp. CT-001-1-CT-001-10.

Rogers CDF, Hao T, Costello SB et al. (2012) Condition assessment of the surface and buried infrastructure - a proposal for integration. Tunnelling and Underground Space Technology 28: 202-211, http:// dx.doi.org/10.1016/j.tust.2011.10.012.

Ryall M (2001) Whole-life costing, maintenance strategies and deterioration modeling. In Bridge Management. Butterworth-Heinemann, Oxford, UK, pp. 309-330. 
Engineering Sustainability

Volume 171 Issue ES2
Sustainability assessment for urban

underground utility infrastructure

projects

Hojjati, Jefferson, Metje and Rogers
Savic DA, Djordjevic S, Cashman A and Saul A (2008) A whole-life cost approach to sewerage and potable water system management. In Dangerous Pollutants (Xenobiotics) in Urban Water Cycle (Hlavinek $\mathrm{P}$, Bonacci O, Marsalek J and Mahrikova I (eds)). Springer, New York, NY, USA, pp. 3-12.

Shaw G, Kenny J, Kumar A and Hood D (2012) Sustainable infrastructure operations: a review of assessment schemes and decision support. Proceedings of 25th ARRB Conference - Shaping the Future: Linking Policy, Research and Outcomes, Perth, Australia.

Spatari S, Betz M, Florin H, Baitz M and Faltenbacher M (2001) Using $\mathrm{GaBi} 3$ to perform life cycle assessment and life cycle engineering. International Journal of Life Cycle Assessment 6(2): 81-84, http://dx. doi.org/10.1007/BF02977842.

Sterling R, Admiraal H, Bobylev N et al. (2012) Sustainability issues for underground space in urban areas. Proceedings of the Institution of Civil Engineers - Urban Design and Planning 165(4): 241-254, http://dx.doi.org/10.1680/udap.10.00020.
Stokes J and Horvath A (2010) Life-cycle assessment of urban water provision: tool and case study in California. Journal of Infrastructure Systems 17(1): 15-24, http://dx.doi.org/10.1061/(ASCE)IS.1943-555X. 0000036.

USGBC (US Green Building Council) (2016) LEED (Leadership in Energy and Environmental Design). USGBC, Washington, DC, USA. See http://www.usgbc.org (accessed 22/04/2016).

Venables R, Venables J and Newton J (2005) Tools for assessing the environmental performance and sustainability of building and civil engineering projects. Proceedings of the 9 th

International Conference on Environmental Science and Technology, Rhodes, Greece, vol A - Oral Presentations, pts A and B, pp. A1596-A1601.

Yik FWH, Burnett J, Jones P and Lee WL (1998) Energy performance criteria in the Hong Kong building environmental assessment method. Energy and Buildings 27(2): 207-219, http://dx.doi.org/10.1016/ S0378-7788(97)00037-6.

\section{How can you contribute?}

To discuss this paper, please email up to 500 words to the editor at journals@ice.org.uk. Your contribution will be forwarded to the author(s) for a reply and, if considered appropriate by the editorial board, it will be published as discussion in a future issue of the journal.

Proceedings journals rely entirely on contributions from the civil engineering profession (and allied disciplines). Information about how to submit your paper online is available at www.icevirtuallibrary.com/page/authors, where you will also find detailed author guidelines. 